\title{
PENGARUH CUACA TERHADAP RETURN SAHAM DI BURSA EFEK INDONESIA
}

\author{
Yulis Maulida Berniz \\ esha816@yahoo.com \\ Cici Widowati \\ widowaticici@gmail.com \\ UNIVERSITAS PERADABAN BUMIAYU
}

\begin{abstract}
Weather factors that significantly affect stock returns on the Indonesia Stock Exchange weather hypothesis is positive and significant effect on stock returns in the Indonesia Stock Exchange. Research using daily data in the form of stock returns obtained from the data center capital markets and daily weather data obtained from the Meteorology and Geophysics Agency (BMG) in Jakarta in the form of ordinal levels. The analytical method used in this research is regression analysis linier.
\end{abstract}

Keywords:

\section{A. PENDAHULUAN}

Pada dasarnya jika kita berbicara tentang manajemen keuangan yang merupakan bagian dari ilmu manajemen yang menyangkut pengelolaan keuangan perusahaan, sebenarnya kita berbicara unsur manusia. Dalam hal ini manusia memegang peranan penting dalam proses pengambilan keputusan keuangan. Pengambilan keputusan itu tidak terlepas dari faktor psikologi manusia itu sendiri dan hal ini ditunjukkan dengan bagaimana perilaku manusia pada saaat menghadapi tantangan resiko adanya ketidakpastian di masa mendatang, oleh karena itu faktor psikologi merupakan hal yang menarik untuk dibicarakan dalam hubungannya dengan proses pengambilan keputusan ekonomi, dalam hal ini ditunjukkan oleh dampak perilaku tersebut terhadap harga pasar.

Dalam proses pengambilan keputusan akan selalu dipengaruhi oleh aspek psikologi orang tersebut. Dalam teori manajemen keuangan tradisional dibangun atas asumsi utama bahwa manusia selalu berpikir rasional dalam setiap langkah pengambilan keputusan yang dilakukan, sehingga setiap keputusan yang diambil adalah pilihan yang sifatnya rasional. Pengambilan keputusan yang rasional akan menyebabkan keuntungan secara ekonomi yang maksimum. Manusia juga diasumsikan selalu mau memperhatikan semua informasi yang tersedia, mampu untuk mengevaluasinya dengan seksama dan mampu mencari jawaban berdasarkan hasil analisis rasional atas informasi tersebut. Dalam hal ini manusia dipandang sebagai makhluk yang mampu membuat keputusan berdasarkan pertimbanganpertimbangan yang sangat logis dan transparan.

Faktor rasionalitas dipengaruhi oleh terbatasnya informasi yang ada. Konsep rasionalitas ditunjukkan dengan teori keuangan yakni pergerakan yang terjadi di pasar secara normal. Dalam kenyataannya, asumsi tentang rasionalitas investor tidak mudah untuk dipenuhi karena sering perilaku tersebut dipengaruhi oleh faktor subyektifitas, emosi, mood, lingkungan, dan faktor 
psikologis lainnya yang justru berperan dominan.

Dalam buku yang dikutip dari Yang (2004) menyebutkan bahwa orang akan memiliki perilaku yang berbeda ketika adanya perbedaan pada cuaca dingin dan cuaca panas, juga menyebutkan bahwa orang akan merasa tidak sabar dan cenderung emosional pada saat temperatur lebih dari $29^{\circ} \mathrm{C}$. Tidak hanya temperatur, indikator cuaca yang lain berperan dalam hal perilaku seseorang diantaranya sinar matahari yang cerah akan membentuk mood yang baik bagi para investor, sehingga akibatnya membuat orang lebih optimis dan lebih bersemangat untuk melakukan analisis terhadap pergerakan saham yang pada akhirnya akan menaikkan harga saham secara agregat di pasar modal. Dalam hal ini cuaca berperan dalam penentuan perilaku manusia.

Adanya perbedaan cuaca pada lokasi perdagangan dapat mempengaruhi penentuan return di pasar, yang disebabkan oleh terjadinya perbedaan pada tingkat emosi dan mood para investor/ traders. Faktor emosi dan mood memegang peranan penting dalam menghadapi situasi ketidakpastian dan beresiko.

Faktor psikologis lainnya yang dapat mempengaruhi kondisi seseorang secara manuisawi yang merupakan kondisi atmosferik dapat berupa regulasi panas tubuh, kebisingan, pencemaran udara serta tekanan udara dan $\mathrm{O}_{2}$, dalam penelitian ini digunakan adalah indikator cuaca berupa curah hujan yang terjadi di lingkungan para investor/traders yang dinilai memiliki pengaruh pada proses pengambilan keputusan.

Penelitian ini dilakukan, mengingat selama ini penelitian yang banyak dilakukan berdasarkan analisis kuantitatif yang terikat dengan rumus-rumus, matematika, dan statistik yang kurang memperhatikan unsur psikologis yang bisa mempengaruhi para investor/traders dalam pengambilan keputusan. Proses pengambilan keputusan, dalam hal ini traders/investor senantiasa melibatkan emosinya termasuk di dalamnya adanya faktor mood, dan salah satunya dipengaruhi oleh indikator faktor cuaca. Indikator faktor cuaca berpengaruh terhadap emosi dan mood seseorang yang kemudian faktor emosi dan mood ini berpengaruh pada perilaku investor/ traders yang tercermin dalam pengambilan keputusan pada bursa saham di pasar modal.

Berdasarkan latar belakang dan rumusan masalah tersebut di atas, penelitian ini bertujuan untuk mengetahui: (1) Bagaimana pengaruh cuaca terhadap terhadap return saham pada sektor aneka industri di Bursa Efek Indonesia, (2) Bagaimana pengaruh cuaca terhadap terhadap return saham pada sektor industri dasar dan kimia di Bursa Efek Indonesia, (3) Bagaimana pengaruh cuaca terhadap terhadap return saham pada sektor konsumsi di Bursa Efek Indonesia.

Manfaat penelitian yang dilakukan adalah sebagai berikut : (1) Memberikan bukti bahwa dalam ilmu manajemen keuangan, hendaknya melibatkan human factor dalam melakukan analisis keuangan, (2) Sebagai bahan pertimbangan bahwa faktor indikator ekonomi berupa analisa kuantitatif memang masih diperlukan, namun dalam ilmu manajemen keuangan yang dibicarakan adalah manusia, sehingga ada faktor lain yang bersifat non kuantitatif yang mempengaruhi investor dalam pengambilan keputusan.

\section{B. METODE PENELITIAN}

1. Variabel Penelitian

Variabel penelitian ini terdiri atas :

a. Variabel terikat/dependent (Y) yakni return saham

b. Variabel bebas/indepenent (X) yakni data cuaca untuk wilayah 
Jakarta yang diwakili

berdasarkan tingkatan/ordinal.

2. Pemilihan Sampel

Sampel yang diambil adalah semua perusahaan yang listed di Bursa Efek Indonesia. Kriteria sampel adalah semua perusahaan manufaktur yang sahamnya aktif pada Januari-Desember tahun 2014-2015 yaitu pada sektor aneka industri, sektor dasar dan kimia, serta sektor barang konsumsi.

3. Data yang Digunakan

Pada penelitian ini menggunakan data antara lain :

a. Data sekunder berupa harga saham harian untuk perusahaan manufaktur untuk sektor aneka industri, sektor dasar dan kimia, serta sektor konsumsi yang sahamnya aktif antara Januari-Desember periode tahun 2014-2015, yang kemudain akan bisa dicari return sahamnya melalui harga saham yang sudah ada, selain itu juga data cuaca harian untuk wilayah Jakarta dimana lokasi Bursa Efek Indonesia berada yang diwakili oleh titik pengamatan cuaca pada daerah Jakarta Pusat. Data diperoleh dari Badan Meteorologi Klimatologi, dan Geofisika (BMKG) Jakarta yang dimulai pada Januari-Desember tahun 2014-2015. Data tersebut berdasarkan skala indeks/ordinal yang terdiri atas enam tingkatan yaitu :

Tingkatan 1 = cuaca hujan sangat lebat (curah hujan lebih dari $100 \mathrm{~mm} /$ hari)

Tingkatan 2 = cuaca hujan lebat (curah hujan 50.1 -100.0 $\mathrm{mm} / \mathrm{hari}$ )

Tingkatan $3=$ cuaca hujan sedang (curah hujan 20.1 - 50.0 $\mathrm{mm} / \mathrm{hari}$ )

Tingkatan $4=$ cuaca hujan ringan (curah hujan $5.1-20.0 \mathrm{~mm} /$ hari) Tingkatan $5=$ cuaca hujan sangat ringan (curah hujan $0.1-5.0$ $\mathrm{mm} /$ hari)

Tingkatan $6=$ cuaca cerah/tidak ada hujan (curah hujan 0 $\mathrm{mm} / \mathrm{hari}$ ).

b. Data primer diperoleh dari jurnal dan buku referensi yang digunakan dalam penyusunan proposal penelitian ini.

4. Teknik Pengumpulan Data

Data yang diperoleh dalam penelitian ini dilakukan melalui teknik tertentu. Teknik pengumpulan data dilaksanakan melalui cara :

a. Pengamatan

Pengamatan yang dimaksudkan disini yakni dengan melihat data sekunder berupa pergerakan harga saham pada Bursa Efek Indonesia saham perusahaan manufaktur untuk sektor aneka industri, sektor dasar dan kimia, serta sektor konsumsi yang listed di BEI aktif JanuariDesember tahun 2014-2015 dan data cuaca per hari pada periode tahun 2014-2015.

b. Studi Pustaka

Studi pustaka diperoleh dari buku, jurnal, dan literatur yang mendukung penelitian, sehingga dengan landasan yang kuat akan diperoleh kesimpulan yang berbobot ilmiah.

5. Analisis Data

Hipotesis yang dibuat menunjukkan adanya pengaruh cuaca terhadap return saham pada Bursa Efek Indonesia. Jika koefisien pada variabel bebas/independent bernilai positif signifikan, maka hipotesis diterima bahwa cuaca berpengaruh positif terhadap return saham atau dengan kata lain, semakin besar tingkatan cuaca (semakin menuju ke arah cerah/tidak ada hujan), maka return 
saham akan semakin besar/tinggi. Sebaliknya, jika semakin rendah tingkatan cuaca (semakin menuju ke arah hujan/hujan lebat sekali), maka return saham akan semakin rendah pula.

6. Teknik Analisis

Penelitian ini menggunakan teknik analisis regresi linier dengan menggunakan alat bantu SPSS 17. Teknik ini digunakan karena metode ini dapat menghasilkan tes yang bersifat kointegrasi, menunjukkan arah pengaruh variabel bebas/independent terhadap variabel terikat/ dependent.

\section{HASIL DAN PEMBAHASAN}

Analisis data dilakukan untuk menguji hipotesis penelitian. Hipotesis penelitian ini diuji dengan analisis regresi linier. Hipotesis yang diuji adalah adanya pengaruh cuaca terhadap return saham pada Bursa Efek Indonesia, dengan rumusan sebagai berikut :

Return saham $=$ f (cuaca)

Jika koefisien variabel bebas (cuaca) bernilai positif dan signifikan, maka hipotesis diterima bahwa cuaca berpengaruh positif terhadap return saham pada sektor aneka industri, sektor industri dasar dan kimia, serta sektor barang konsumsi.

Pengaruh Cuaca terhadap Return Saham pada Sektor Aneka Industri :

Hasil uji regresi linier untuk beberapa sektor diperoleh persamaan sebagai berikut :

1. Sektor Aneka Industri $\mathrm{Y}=0,213+$ $(-0,036) \mathrm{X}_{1}$

2. Sektor Dasar dan kimia $\mathrm{Y}=-0,003+$ $0,001 \mathrm{X}_{1}$

3. Sektor barang konsumsi $\mathrm{Y}=0,000+$ $3,340 \mathrm{X}_{1}$

Dari persamaan tersebut diperoleh analisis bagaimana pengaruh cuaca terhadap return saham di BEI :

\begin{tabular}{|l|l|l|l|l|}
\hline \multicolumn{5}{|c|}{ Variabel Dependen (Return Saham) } \\
\hline $\begin{array}{l}\text { Koefisien } \\
\mathbf{X}_{1}\end{array}$ & Nilai t & $\begin{array}{c}\text { Signifi- } \\
\text { kansi }\end{array}$ & $\begin{array}{c}\text { Adjusted } \\
\mathbf{R} \\
\text { Square }\end{array}$ \\
\hline $\begin{array}{l}\text { Sektor } \\
\text { Industri }\end{array}$ & $-0,036$ & $-2,562$ & 0,010 & 0,000 \\
\hline $\begin{array}{l}\text { Sektor Dasar } \\
\text { Kimia }\end{array}$ & 0,001 & 10,809 & 0,000 & 0,022 \\
\hline $\begin{array}{l}\text { Sektor } \\
\text { Barang } \\
\text { Konsumsi }\end{array}$ & 3,340 & 0,76 & 0,939 & 0,000 \\
\hline
\end{tabular}

Dari hasil regresi linier bisa disimpulkan bahwa :

1. Nilai konstanta untuk sektor aneka industri sebesar 0,213, menunjukkan tanpa ditambahkan dengan variabel $\mathrm{X}$ nilai perubahan return saham akan terbentuk sebesar 0,213.

Nilai konstanta untuk sektor dasar dan kimia sebesar - 0,003 menunjukkan tanpa ditambahkan dengan variabel $\mathrm{X}$ nilai perubahan return saham akan terbentuk sebesar 0,003. Nilai konstanta untuk sektor dasar dan kimia sebesar 0,000 menunjukkan tanpa ditambahkan dengan variabel $\mathrm{X}$ nilai perubahan return saham akan terbentuk sebesar 0,000.

2. Nilai koefisien untuk sektor aneka industri sebesar -0,036, menunjukkan bahwa ketika akan ada kenaikan cuaca (semakin menuju hujan lebat), maka akan ada penurunan return saham pada sektor aneka industrinya. Tanda negatif berarti bahwa ketika cuaca semakin tinggi tingkatannya (semakin menuju hujan lebat), maka return saham akan mengalami penurunan sebesar 0,036 .

Nilai koefisien untuk sektor dasar dan kimia sebesar 0,001 menunjukkan bahwa ketika akan ada kenaikan cuaca (semakin menuju hujan lebat), maka akan ada kenaikan return saham pada sektor aneka industrinya.

Nilai koefisien untuk sektor barang konsumsi sebesar 3,34000000 menunjukkan bahwa ketika akan 
ada kenaikan cuaca (semakin menuju hujan lebat), maka akan ada kenaikan return saham pada sektor barang konsumsi.

3. Pengujian signifikansi koefisien regresi dengan menggunakan uji t. Uji ini digunakan untuk menguji variabel independen secara terpisah terhadap return saham di BEI. Cara yang dilakukan dengan membandingkan probabilitas/ sig t dengan alpha $5 \%$ yaitu 0,05 . Hasil dari tabel disimpulkan sebagai berikut :

- Sektor aneka industri nilai probabilitas (sig t) $0,010<0,05$, yang berarti terdapat pengaruh negatif (koefisien -0,036) signifikan terhadap return saham

- Sektor dasar dan kimia nilai probabilitas (sig t) $0,000<0,05$, yang berarti terdapat pengaruh positif signifikan terhadap return saham

- Sektor barang konsumsi nilai probabilitas (sig t) 0,939>0,05, yang berarti tidak terdapat pengaruh positif signifikan terhadap return saham.

4. Adjusted R Square masing-masing sektor sebesar :

- Sektor aneka industri sebesar 0\%, yang berarti cuaca tidak memiliki pengaruh dalam return saham

- Sektor dasar dan kimia sebesar 0,022 atau $2,2 \%$, yang berarti cuaca memiliki pengaruh terhadap return saham di sektor dasar dan kimia sebesar 2,2\%, sisanya sebesar $97,8 \%$ dipengaruhi oleh variabel lain.

- Sektor barang konsumsi sebesar $0 \%$ yang berarti cuaca tidak memiliki pengaruh dalam return saham.

5. Berdasarkan hipotesis yang ada hipotesis kedua yaitu bahwa cuaca memiliki pengaruh positif terhadap return saham pada sektor dasar dan kimia di Bursa Efek Indonesia, terbukti. Jadi hipotesis kedua diterima.

\section{KESIMPULAN}

Ada beberapa hal yang bisa disimpulkan yaitu :

1. Pada sektor aneka industri tidak terbukti bahwa cuaca berpengaruh positif terhadap return saham karena yang terjadi cuaca berpengaruh negatif terhadap return yang artinya setiap kenaikan cuaca (semakin menuju ke arah cerah), maka return saham akan mengalami penurunan, hal ini dikarenakan pada saat cuaca panas, dimana secara psikologis manusia cenderung mengalami keletihan fisik dan kelesuan/kurang agresif dalam pengambilan resiko investasi.

2. Pada sektor dasar dan kimia terbukti bahwa cuaca berpengaruh positif terhadap return saham, yang artinya setiap kenaikan cuaca (semakin menuju ke arah cerah) maka return saham akan mengalami kenaikan juga.

3. Pada sektor barang konsumsi tidak terbukti bahwa cuaca berpengaruh positif terhadap return saham, yang terjadi pada sektor barang konsumsi cuaca tidak berpengaruh positif terhadap return saham, hal ini bisa tergantung pada sistem perdagangan yang berlaku juga. 


\section{DAFTAR PUSTAKA}

Cao, M., \& Wei, J. (2004). Stock market return: A temperature anomaly. Working Paper. Canada.

Goetzman, W. N., \& Zhu, Ning. (2002). Rain or Shine: Where is the Weather Effect?. Working Paper.

Hirshleifer, D., \& Shumway, T. (2003). Good day sunshine: Stock returns and the weather. Journal of Finance, 58 (3), 1009-1032.

Loughran, T., \& Schultz, P. (2003). Weather, stock return, and the impact of localized trading. Journal of Financial and Quantitative Analysis.

Mirza, H. H., Asghar, M. J. K. A., \& Mushtaq, N. (2012). Stock market returns and weather anomaly: Evidence from an emerging economy. Working Paper. Pakistan.

Musdalifah A (2013). Filsafat Teori Portofolio Modern. Artikelku99.blogspot.com.

Pardo, A., \& Valor, E. (2003). Spanish stock return: Rational or weather influenced.

Saunders, E. M. (1993). Stock price and wall street weather. The American Economic Review, 83 (5), 1337-1345.

Sutrisno. (2001). Manajemen Keuangan: Teori, Konsep, dan Aplikasi. Yogyakarta: Ekonisia.

Tufan, \& Hamarat. (2003). Weather Effect: An Evidence from Turkish Stock Exchange. Working Paper.

Yang, T. (2004). How does the weather affect the stock market? Empirical evidence in Taiwan. Taiwan: Feng China University.

Yulis M. B, (2006), Analisis Pengaruh Cuaca terhadap Harga Saham pada Bursa Efek Jakarta, Universitas Islam Indonesia, Jogjakarta. 